\title{
Response of grazing snails to phosphorus enrichment of modern stromatolitic microbial communities
}

\author{
JAMES J. ELSER,, JOHN H. SCHAMPEL,$*$ MARCIA KYLE,$*$ JAMES WATTS, ${ }^{*}$ EVAN W. CARSON,$*$ \\ THOMAS E. DOWLING ${ }^{*}$ CAROL TANG ${ }^{+}$AND PETER D. ROOPNARINE ${ }^{+}$ \\ *School of Life Sciences, Arizona State University, Tempe, AZ; and NASA Astrobiology Institute, USA \\ ${ }^{+}$California Academy of Sciences, Golden Gate Park, San Francisco, CA; and NASA Astrobiology Institute, USA
}

\section{SUMMARY}

1. The effects of added phosphorus (P) on the growth, P and RNA : DNA contents, and survivorship of snails grazing on laminated microbial mats (living 'stromatolites') were examined in the Rio Mesquites at Cuatro Ciénegas, Mexico (total P, c. $0.60 \mu \mathrm{mol} \mathrm{L}^{-1}$ ) to test the hypothesis that strong P-limitation of microautotroph growth produces a stoichiometric constraint on herbivores because of mineral P-limitation.

2. In a 3-week experiment performed in summer 2001, addition of phosphorus $\left(+15 \mu \mathrm{mol} \mathrm{L}{ }^{-1}\right)$ resulted in a strong decline in stromatolite biomass $\mathrm{C}: \mathrm{P}$ ratio from very high levels (c. $2300: 1$ by atoms) to moderate levels (c. $550: 1$ ). The endemic hydrobiid snail Mexithauma quadripaludium responded to P-enrichment with elevated body P content and higher RNA : DNA ratios, especially for small animals likely to be actively growing. This positive response is consistent with the existence of a stoichiometric constraint on snail growth.

3. In a longer experiment ( 8 weeks) involving a more moderate $\mathrm{P}$ enrichment $\left(+5 \mu \mathrm{mol} \mathrm{L}{ }^{-1}\right)$ in summer 2002, $\mathrm{P}$ enrichment reduced stromatolite $\mathrm{C}: \mathrm{P}$ ratio from moderate values in control treatments (c. 750$)$ to very low values $(<100: 1)$. Snails responded to stromatolite P-enrichment with increased body $\mathrm{P}$ content but, in contrast to the first experiment, with lower RNA : DNA ratio, lower growth rates, and higher mortality.

4. These contrasting results suggest that both very high and very low biomass $C: P$ ratios in stromatolites are detrimental to M. quadripaludium performance, leading us to hypothesise that these herbivores live on a 'stoichiometric knife edge'.

Keywords: Cambrian explosion, phosphorus, snails, stoichiometry, stream, stromatolites

\section{Introduction}

Microbial mats that generate laminated structures are the dominant form of life represented in the early part of Earth's fossil record. These life forms existed for billions of years prior to the evolution of eukaryotes, leaving behind extensive deposits of their remains. These 'stromatolites' are a primary means of recon-

Correspondence: James Elser, School of Life Sciences, Arizona State University, Tempe, AZ 85287, USA.

E-mail: j.elser@asu.edu structing Earth's early environments (Grotzinger \& Knoll, 1999). However, stromatolites essentially disappear from the fossil record around 500 million years ago, simultaneous with the relatively sudden (in geologic time) appearance of complex, large-bodied metazoans. These events terminated the Precambrian epoch and have long intrigued palaeontologists and evolutionary biologists (Knoll \& Carroll, 1999; Zhuravlev \& Riding, 2001) curious about the environmental triggers of this Cambrian 'explosion'. To date, the leading explanation candidates have been increases in atmospheric oxygen (Valentine, 1973; Thomas,

(ㄷ) 2005 Blackwell Publishing Ltd 
1997), delayed appearance of key genomic innovations (Erwin, 1993; Raff, Marshall \& Turbeville, 1994; Davidson, Peterson \& Cameron, 1995), and increases in total productivity associated with enhanced nutrient inputs (Cook \& Shergold, 1984; McMenamin, 1988; Brasier, 1990). While effects of total productivity seem plausible, no hypotheses involving the quality of primary production for supporting animal growth have yet been proposed, even though food quality is a critical factor regulating herbivore dynamics in modern food webs (White, 1993; Sterner \& Hessen, 1994). The theory of ecological stoichiometry (Sterner \& Elser, 2002) suggests a means by which such a food quality hypothesis might be relevant for understanding the events surrounding the Cambrian explosion.

Ecological stoichiometry highlights the importance of mismatches in the elemental composition of food items (i.e. biomass of autotrophic algae or higher plants) and consumers (i.e. herbivores) in constraining consumer growth and production. In general, autotroph biomass has variable but generally high $\mathrm{C}$ : nutrient ratio, especially under nutrient limitation, while individual animals have low $\mathrm{C}$ : nutrient ratios in their bodies and homeostatically regulate those ratios around values specific to species or developmental stages (Sterner \& Elser, 2002). Furthermore, accumulating evidence indicates that $\mathrm{C}: \mathrm{P}$ and $\mathrm{N}: \mathrm{P}$ ratios in invertebrates are strongly influenced by their relative allocation to P-rich ribosomal RNA necessary to support growth rates during development (Elser et al., 2000b). Thus, the evolution of particular developmental strategies may ultimately be constrained by stoichiometric imbalance if animals do not have access to P-rich food items. Finally, stoichiometric theory has identified strong non-linearities in herbivore response to autotroph abundance under nutrient limitation, such that, at high levels of autotroph abundance, herbivores suffer severe growth penalities because of food quality constraints and thus may be unable to invade environments already dominated by high biomasses of autotrophs having high $\mathrm{C}$ : nutrient ratio (Andersen, 1997; Loladze, Kuang \& Elser, 2000; Urabe et al., 2002).

The preceding discussion suggests a hypothetical scenario for the Precambrian period, when, for billions of years, Earth's ecosystems were dominated by microbial biomass (autotrophic Cyanobacteria and, eventually, eukaryotic algae; osmotrophic Bacteria and Archaea) with particle-ingesting herbivores
Effects of stromatolite P enrichment on grazers

essentially absent. Perhaps microbial mats during the Precambrian, such as those generating widespread stromatolite remains in the fossil record, suffered severe nutrient $(\mathrm{P})$ limitation, resulting in extremely high biomass $\mathrm{C}: \mathrm{P}$ ratios, and thus the evolution of large multicellular herbivores was prevented in Precambrian ecosystems because of stoichiometric constraints (Elser, 2003). This state was maintained until environmental changes lowered microbial $\mathrm{C}: \mathrm{P}$ ratio to a level that could support large, fast-growing, Metazoa. Palaeoenvironmental evidence suggesting the feasibility of such a scenario exists (Brasier \& Lindsay, 1998; Bjerrum \& Canfield, 2002). However, the potential validity of such a scenario would be bolstered if there were evidence for the operation of such stoichiometric constraints in modern ecosystems inhabited by laminating microbial mats. We sought to test these ideas by examining the response of snails to experimental $\mathrm{P}$ fertilisations of living microbial communities that actively generate diverse laminated structures (hereafter, 'stromatolites') in a unique ecosystem, Cuatro Ciénegas (Mexico) and do so in the presence of grazing metazoans (snails).

\section{Methods}

Study site

Experiments were performed using oncoid (eggshaped) stromatolites found in the Rio Mesquites, a spring-fed stream at Cuatro Ciénegas, Mexico. The oncoids used were c. $8-10 \mathrm{~cm}$ in major dimension with a reticulated surface created by active concretion by the microbial assemblage including a relatively brittle framework of 'florets' c. $0.5-1.0 \mathrm{~cm}$ in dimension. Between 1998 and 2003 when we have sampled this system, concentrations of total $\mathrm{P}$ and SRP averaged c. $0.54 \mu \mathrm{mol} \mathrm{L}^{-1}$ (range: 0.18-1.06) and c. $0.59 \mu \mathrm{mol} \mathrm{L}^{-1}$ (range: $0.10-1.47$ ), respectively. Further details about the Cuatro Ciénegas basin (CCB, hereafter) and local conditions in the Rio Mesquites are reported in Elser et al. (2005). A unique feature of the springs at Cuatro Ciénegas is the co-occurrence of metazoans with living stromatolites. Specifically, more than a dozen hydrobiid snail species are present in CCB (Hershler, 1985). The endemic species Mexithauma quadripaludium (Taylor) is of particular interest, as it grazes primarily on hard surfaces such as rock benches or stromatolites. Another common 
hydrobiid snail, Nymphophilus minckleyi (Taylor), can also be found on hard substrata but primarily inhabits the surfaces of aquatic macrophytes. Mexithauma quadripaludium was used in the grazing studies we report here.

\section{Set-up of experiment 1}

During summer 2001, we performed a P-enrichment experiment in which replicate $(n=8)$ oncoid stromatolites collected from the Rio Mesquites were assigned either to unenriched control $(-\mathrm{P})$ or $\mathrm{P}$-enrichment $(+\mathrm{P})$ treatments. Enriched treatments were incubated in waters receiving a $\mathrm{P}$ fertilisation of $15 \mu \mathrm{mol} \mathrm{Na}_{2} \mathrm{HPO}_{4} \mathrm{~L}^{-1}$. We did not control $\mathrm{pH}$ but measurements of Rio Mesquites waters before and after fertilisation detected no change in $\mathrm{pH}$. All snails were removed from stromatolites at the beginning of the experiment and then five snails per stromatolite (the approximate average at the time of sampling) were randomly returned to graze for the duration of the experiment. Incubations took place in translucent plastic containers containing c. $1 \mathrm{~L}$ of water from the Rio Mesquites, which was exchanged daily over a period of 21 days. Containers were held at ambient temperature to match the Rio Mesquites and experienced the natural light-dark cycle with shading to reduce light intensity to $c .50 \%$ of ambient irradiance. At the end of the experiment, microbial biomass of each stromatolite was sampled for determination of elemental composition as described below and individual snails were retained for later analysis of body $\mathrm{P}$ content or of nucleic acids (as an indicator of growth rate, as RNA : DNA ratio is generally positively correlated with growth rate; Elser et al., 2000b).

\section{Set-up of experiment 2}

Details regarding the 8-week experiment performed in summer 2002 are presented in Elser et al. (2005). In brief, duplicate oncoid stromatolites were suspended in each of twelve 20-L buckets, half of which received $P$ fertilisation via enrichment of $5 \mu \mathrm{mol} \mathrm{Na} \mathrm{HPO}_{4} \mathrm{~L}^{-1}$ to stream water replenished twice daily. Suspending the stromatolites $5 \mathrm{~cm}$ above the bottom of the bucket prevented snails from crawling off of the stromatolite and thus not experiencing the appropriate food environment. Each pair of stromatolites was occupied by $M$. quadripaludium chosen to be representative of the size range of snails present in the stream and applied at ambient snail density (c. 12 per stromatolite at the time of sampling). Colour-coded paint dots allowed identification of individual snails at the end of the experiment. Prior to placement of snails on the stromatolites, the body mass of all individuals was measured, as wet mass, and final mass measured similarly at the termination of the experiment.

\section{Stromatolite biomass and elemental composition}

Data presented here focus on results for scrapings of surficial materials on individual stromatolites, as these would be considered representative of biomass available for snail consumption. Stromatolites were scraped to a uniform depth (c. $0.5 \mathrm{~mm}$ ) and the materials dried and held in a freezer until later analysis. Organic matter content was determined using a method of drying and weighing followed by combustion and re-weighing and then converting organic matter estimates to a carbon basis using a conversion factor $(36.6 \% ; 1.9 \% \mathrm{SD})$ obtained via direct elemental analysis. Phosphorus content of the same material was determined by dissolving ashed material of known initial dry mass in sulphuric acid, followed by spectrophotometric analysis. Details regarding the methods for preparation and analysis of stromatolite organic matter and P content samples are presented in Elser et al. (2005).

\section{Snail elemental composition and nucleic acid content}

Soft body parts of snails to be analysed for P content were removed from shells, dried, and held frozen until analysis. Samples were weighed as an estimate of animal body size and then analysed for $\mathrm{P}$ content using persulphate digestion followed by spectrophotometric analysis (APHA, 1999). Samples for nucleic acid analysis could not be handled in this manner because nucleic acids are easily degraded and thus animals could not be dried to estimate body mass. 'Soft' body parts of these snails were preserved in a nucleic acid stabiliser (RNALater ${ }^{\mathrm{TM}}$, Ambion, Austin, TX, U.S.A.) for later analysis of nucleic acids using a modified dual fluorochrome procedure (Gorokhova \& Kyle, 2002). To determine body mass, in 2001 live snails were photographed from a standard perspective, and the projected area of that image from image analysis was used to convert to snail wet mass using a 
conversion function $\left(P<0.0001, r^{2}=0.97\right)$ obtained from later analysis of parallel samples that were first photographed followed by wet mass determination (after removing excess water on paper towelling) using a Mettler (Mettler-Toledo Inc., Columbus, $\mathrm{OH}$, U.S.A.) model AX205 electrobalance (precision: $\pm 0.01 \mathrm{mg}$ ). In 2002 , the wet mass of each snail was directly measured in the field using a Sartorius (Sartorius AG, Goettingen, Germany) EC150 S electrobalance $( \pm 1 \mathrm{mg})$.

\section{Snail growth and survivorship}

In 2002, growth in terms of wet mass was calculated for each snail as $\mu\left(\mathrm{d}^{-1}\right)=\ln (F / I) / t$, where $F$ and $I$ are the final and initial body masses and $t$ is the length of the experiment in days. As growth rate generally exhibits strong allometric declines as an animal increases in size, effects of experimental treatments on growth rates were assessed while taking initial body mass into account (see Statistical analysis below). Survivorship was expressed as a percentage of originally marked individuals recovered in each bucket at the end of the experiment.

\section{Statistical analysis}

Since we expected various parameters (P content, RNA : DNA ratio, growth rate) to show substantial size-dependence, the responses of snails to stromatolite P-enrichment were evaluated while taking individual snail size into account. First, response variables within each experiment were analysed by General Linear Models (GLM) with P treatment as independent variable and body size as covariate. The significance of the treatment-body size interaction was used to test for homogeneity of slope. Significant differences $(P<0.05)$ were then interpreted directly as an indication that stromatolite P-enrichment had affected that variable in a bodysize dependent manner. If the GLM indicated homogeneity of slope, then data were entered into analysis of covariance (ANCOVA) to examine the effect of treatment while correcting for the effect of individual body size, which was used as a covariate. For the 2002 experiments, it was necessary to logtransform the data prior to statistical tests in order to meet the assumption that residuals were normally distributed with similar variance.

\section{Results}

Experiment 1 (2001)

As expected, adding $\mathrm{P}$ to Rio Mesquites water decreased stromatolite $\mathrm{C}: \mathrm{P}$ ratio from values of c. 2300-550 (Fig. 1a). These changes were statistically significant $(t=11.8$, d.f. $=14, P<0.001)$ but even in
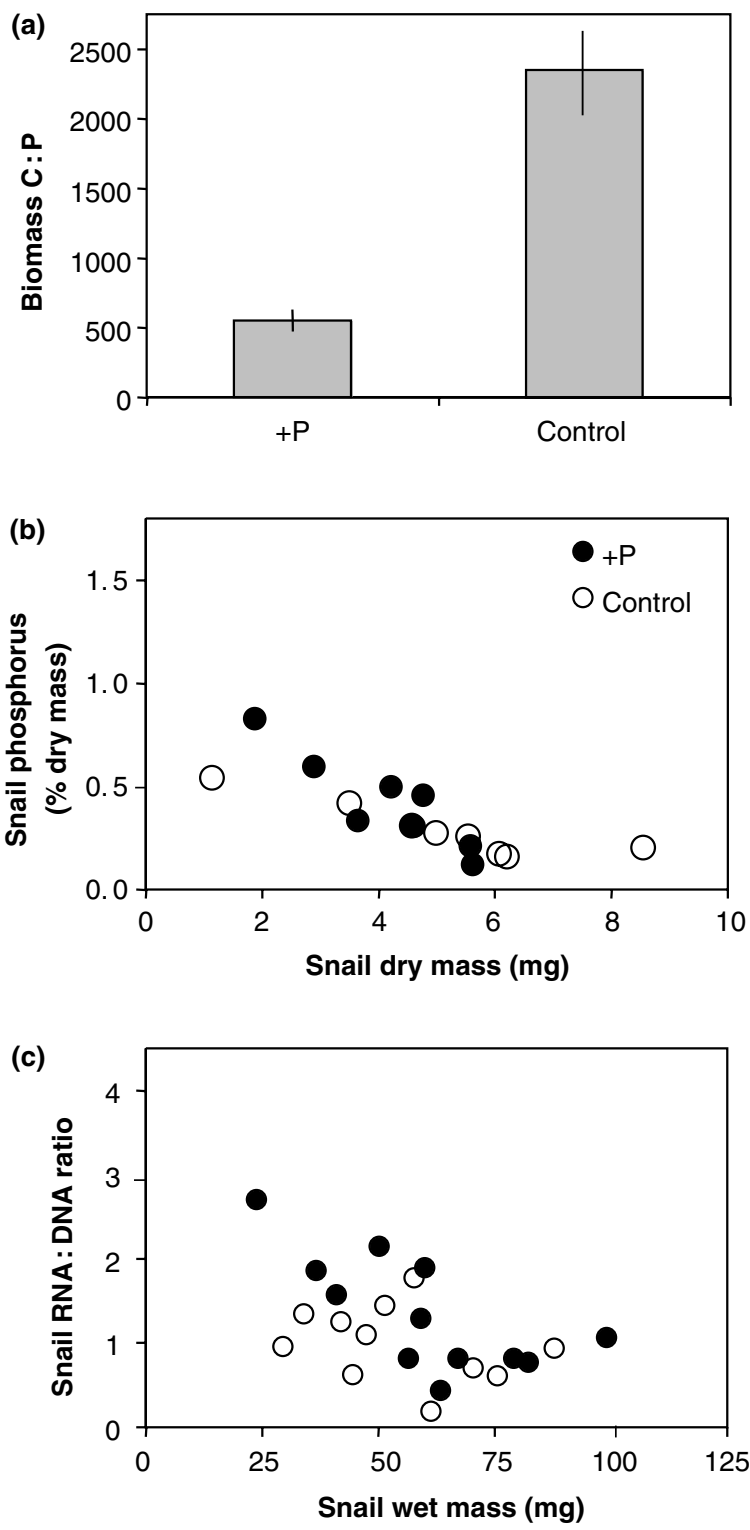

Fig. 1 Responses of stromatolites and Mexithauma snails to a 3week P-enrichment in summer 2001. (a) Stromatolite C : P ratio (atomic) at the end of the experiment (error bars indicate $\pm 95 \%$ confidence limits). (b) Size-dependence of P content ( $\%$ dry mass) of snails from $-\mathrm{P}$ and $+\mathrm{P}$ stromatolites. (c) Size-dependence of RNA : DNA ratio of snails from $-\mathrm{P}$ and $+\mathrm{P}$ stromatolites. 
$\mathrm{P}$-enriched conditions $\mathrm{C}: \mathrm{P}$ values remained rather high, exceeding, for example, the $\mathrm{C}: \mathrm{P}$ ratio (c. 300) that induces P-limitation of crustacean herbivores (see Discussion; Sterner \& Elser, 2002). Effects of P-enrichment were transmitted to the herbivore trophic level: in GLM, the slopes of the relationship between snail P-content and body mass for the two enrichment treatments differed significantly $\left(F_{1,15}=13\right.$, $P<0.005)$, as is clear in Fig. $1 \mathrm{~b}$ where small snails in the $+\mathrm{P}$ treatment had considerably elevated $\% P$ values. For the RNA : DNA ratio, slopes with body size were not statistically different for the two treatments in the GLM analysis so the data were subjected to ANCOVA. Stromatolite P enrichment had a significant effect on log-transformed RNA : DNA ratio $\left(F_{1,20}=4.53, P<0.05\right)$ with generally higher ratios for snails in the $+\mathrm{P}$ treatment (Fig. 1c), consistent with a faster growth.

\section{Experiment 2 (2002)}

Responses of stromatolite biomass and $\mathrm{C}: \mathrm{P}$ ratio to added $\mathrm{P}$ are reported in Elser et al. (2005) and summarised here. No effects on total organic matter content in the surficial layers were observed but large changes in $\mathrm{C}: \mathrm{P}$ ratio of this biomass occurred. Importantly, the $\mathrm{C}: \mathrm{P}$ ratios of stromatolites upon collection and in unfertilised treatments (with or without snails) were lower than in 2001 (500-1000 vs. c. 2500). P-enrichment reduced the $C: P$ ratio even further, to values $<150$ at the mid-point sampling and $<100$ at the end. The response to $\mathrm{P}$ was highly significant $(P<0.001)$.

As in the 2001 experiment, snail $\mathrm{P}$ content and RNA : DNA ratio (log-transformed) decreased with increasing snail size (Fig. 2a) but the size-dependence was not affected by $\mathrm{P}$ enrichment $(P>0.16$ in GLM). Thus, the effect of $P$ on these parameters was tested by ANCOVA, which indicated a significant effect on both $P$ content $\left(F_{1,15}=6.30, P<0.05\right)$ and the RNA : DNA ratio $\left(F_{1,40}=4.26, P<0.05\right)$. Examination of Fig. 2 indicates that, as in 2001, $P$ enrichment resulted in higher snail P-contents but, unlike 2001, snail RNA : DNA ratios were lower in $+\mathrm{P}$ relative to control snails, suggesting a negative impact of stromatolite P-enrichment on snail growth rate. Eighty-eight colour-coded snails (59 from the control treatment, 29 from the $+\mathrm{P}$ treatment) were recovered from the buckets at the end of the experiment, permitting
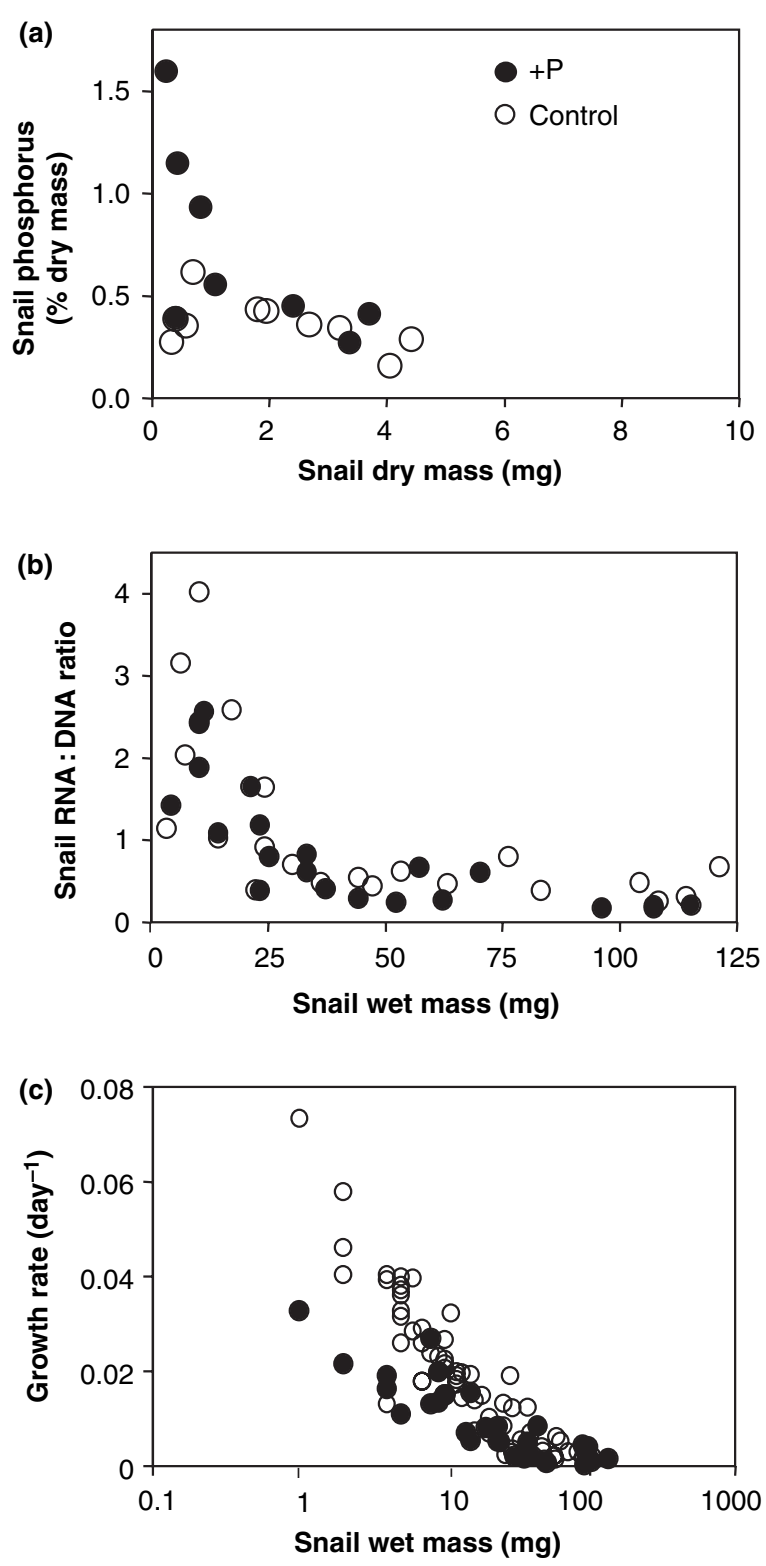

Fig. 2 Responses of Mexithauma snails to an 8-week P-enrichment in summer 2002. (a) Size-dependence of snail P content for snails in P-enriched $(+\mathrm{P})$ and unenriched control treatments. (b) Size-dependence of RNA : DNA ratio for snails in P-enriched and control treatments. (c) Size-dependence of specific growth rate of snails as a function of initial body size (wet mass) in unenriched (control) and enriched $(+\mathrm{P})$ treatments. Note that in this panel the $x$-axis has been log-transformed.

calculation of individual growth rates. Snail growth rate declined with snail body size (Fig. 2c) and GLM indicated that the slopes of these size relationships differed significantly for the two treatments $\left(F_{1,97}=\right.$ 5.14, $P<0.05)$. The convergence of the growth 
relationships at larger size reflects the ontogenetic decline of growth in both treatments, as snails that were already near their maximum size at the start of the experiment could not have had their growth impacted by the $\mathrm{P}$ enrichment. Snails in the $+\mathrm{P}$ treatment not only grew more slowly than controls in the 2002 experiment, they also experienced elevated rates of mortality (Fig. 3) compared with the control treatment $(t=3.58$, d.f. $=10, P<0.01)$.

\section{Discussion}

It appears that $\mathrm{P}$ supply has strong effects on grazing snails at the base of food webs at Cuatro Ciénegas. However, these effects are variable: in 2001, P enrichment and lower stromatolite $\mathrm{C}: \mathrm{P}$ ratio apparently had positive effects on snails (higher $\mathrm{P}$ content and RNA : DNA ratios) whereas in $2002 \mathrm{P}$ fertilisation and lower stromatolite $\mathrm{C}: \mathrm{P}$ ratio had strong negative effects, as indicated by lower RNA : DNA ratios despite higher $\mathrm{P}$ content, lower growth rates, and increased mortality. Interpretation of these contrasting outcomes is facilitated by extensive studies of the effects of food C : P ratio on growth and reproduction of the microcrustacean Daphnia (Sterner \& Hessen, 1994; Sterner \& Schulz, 1998).

The increased snail $\mathrm{P}$ content and RNA : DNA ratio in response to lowering the $\mathrm{C}: \mathrm{P}$ ratio of stromatolite biomass during the short-term experiment in 2001 (Fig. 1) is consistent with relief of a

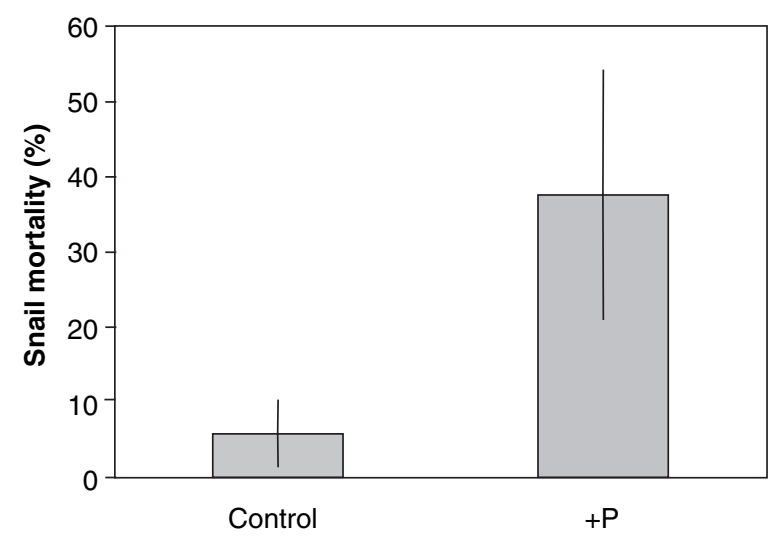

Fig. 3 Mortality of Mexithauma snails during the 2002 experiment expressed as a percentage based on the fraction of marked animals that were recovered from each replicate at the end of the experiment. Error bars indicate $\pm 95 \%$ confidence limits. The two treatments were significantly different from each other in a $t$-test $(P<0.05)$. stoichiometric constraint as previously observed in many studies in which Daphnia are offered algal food with $\mathrm{C}: \mathrm{P}$ exceeding the 'threshold elemental ratio' (TER; Urabe \& Watanabe, 1992). The TER is the food elemental ratio above which the consumer's growth rate becomes potentially limited by the nutrient content of its diet. According to stoichiometric theory (Sterner \& Elser, 2002), a consumer's TER is a function of its own body nutrient content (e.g. C: $\mathrm{P}$ ratio) and its relative maximal assimilation efficiencies for $\mathrm{C}$ and nutrient. Indeed, a variety of studies have consistently shown depression of Daphnia growth and reproduction when food is provided at $\mathrm{C}: \mathrm{P}$ ratios exceeding Daphnia's TER for P (c. 250; Urabe \& Sterner, 1996; DeMott, Gulati \& Siewertsen, 1998; Boersma, 2000). The stromatolite-grazing snail Mexithauma used in our study has a relatively high body $\mathrm{C}: \mathrm{P}$ ratio (c. 277, based on an average P content of $0.44 \%$ over all snails included in Fig. 1 and 2 and assuming $45 \%$ C in snail dry mass) compared with other invertebrate herbivores that have been studied (crustacean zooplankton: 116, insects: 124; Elser et al., 2000a). Thus, we would expect the TER of Mexithauma for $\mathrm{P}$ to be somewhat higher. A rough conservative estimate assuming an average body $C: P$ ratio of 277 , a maximal growth efficiency for $P$ of $100 \%$, and a maximal growth efficiency for $C$ of $50 \%$, yields a value of $c$. 550. For smaller snails with higher body $\mathrm{P}$ content, this TER would be correspondingly lower. The C:P ratio of stromatolite biomass in 2001 was extremely high (c. 2300), exceeding values even for nutrient-poor terrestrial foliage (Elser et al., 2000a), and considerably exceeding this estimated TER for Mexithauma. Thus, it is reasonable that decreasing stromatolite $\mathrm{C}: \mathrm{P}$ ratios from c. 2300 to $c .550$ in response to $\mathrm{P}$ fertilisation resulted in increased performance of Mexithauma, as indicated by increased RNA : DNA ratio. Note that focussing on smaller, more P-rich, snails would lower the estimated TER value somewhat (from c. 550 to c. 290 , focussing on snails $<2 \mathrm{mg}$ wet mass), strengthening the inference that P-limitation is likely for these snails. It is also important to note that the number of animals involved in this experiment was somewhat limited and, in particular, relatively few small-sized snails were involved. Thus, indications of the stimulation effect of added $\mathrm{P}$ on snail performance would be strengthened by 
additional experiments involving a larger number of smaller animals.

In contrast to the experiment in 2001, in the longerterm experiment in $2002 \mathrm{P}$ fertilisation lowered stromatolite $C: P$ to values $<100$, far below the estimated TER and even below TER values for P-rich animals such as Daphnia. P-enrichment had extremely deleterious effects on Mexithauma: lower RNA : DNA ratio (Fig. 2b), lower growth rates (Fig. 2c), and increased mortality (Fig. 3), especially in smaller snails. This unexpected result is easier to understand when one considers the absolute values of stromatolite C : P ratio in 2002 relative to 2001 in light of recent observations of the effects of extremely P-rich food on Daphnia. In 2002, average C : P ratios of stromatolites at the start of the experiment and in unfertilised stromatolites at the mid-point and end of the experiment ranged from $c .500$ to $c .1000$ and $\mathrm{P}$ fertilisation produced C : P ratios that were $<150$ at the mid-point and $<100$ at the end of the experiment. These values for P-enriched stromatolites are lower than the great majority of observations of phytoplankton and foliar $C: P$ ratio in the compilation of Elser et al. (2000a). In contrast, in 2001 initial and final C : P values (Fig. 1) for unfertilised stromatolites were much higher (c. 2300, as noted above) and P-enrichment resulted in reduced but still relatively high $\mathrm{C}: \mathrm{P}$ values (c. 550). One possible mechanism for the reduced performance of snails on P-enriched stromatolites in 2002 is that Penrichment shifted the microbial community towards less palatable taxa. However, as shown in Elser et al. (2005), the main response to P-enrichment at the community level was increased relative abundance of diatoms. Since diatoms are generally considered to be higher quality food items than cyanobacteria (e.g. Brett, Muller-Navarra \& Park, 2000), this shift seems unlikely to be responsible for the observed negative effect of P-enrichment on snails in 2002. Another possible mechanism is that $\mathrm{P}$ enrichment shifted the microbial community towards enhanced $\mathrm{N}$-limitation, resulting in increased biomass $\mathrm{C}: \mathrm{N}$ ratio and subsequent $\mathrm{N}$-limitation of the snails themselves. However, assessments of stromatolite $\mathrm{C}: \mathrm{N}$ ratio indicated no change in organic matter $\mathrm{C}: \mathrm{N}$ ratio in response to $\mathrm{P}$ enrichment (Elser et al., 2005) and thus we think that this explanation for poor snail performance under Penrichment is unlikely.

Another possibility is that P-enrichment in 2002 resulted in stromatolite biomass that was unnaturally rich in $\mathrm{P}$ and thus poisoned or otherwise inhibited the growth and metabolism of Mexithauma. The feasibility of this scenario is supported by recent findings on the effects of extremely P-rich food on Daphnia (Plath \& Boersma, 2001). In their study, Daphnia growth increased as food C: P was lowered from values exceeding the TER, as in previous studies. However, when food $C: P$ ratio was further reduced to very low levels $(<100)$ below those of Daphnia biomass itself, growth declined and thus a plot of growth versus food C : P ratio was hump-shaped. Their behavioural studies indicated that Daphnia feeding on low C : P algae were viable but had greatly reduced feeding rates. Plath \& Boersma (2001) interpreted this as indicating that Daphnia fed primarily to meet their P requirements and, once that $P$ requirement had been met, they ceased feeding and consequently starved themselves (for $\mathrm{C}$ or energy) amidst plentiful food. While the role of such behavioural responses is unclear for our study, a similar scenario may have occurred in our 2002 experiments, as stromatolite $C: P$ ratios were reduced to extremely low values, drastically below the estimated TER for Mexithauma and reaching values similar to the low values involved in the study of Plath \& Boersma (2001). However, in our case we are unable to assess the means by which these negative effects were generated; behavioural responses (as in Daphnia), direct physiological toxicity of the added $\mathrm{P}$, as well as indirect toxic effects caused by the P-enrichment, remain possibilities. Interestingly, a unimodal response of growth to dietary $\mathrm{C}: \mathrm{P}$ ratio has also been recently reported for the tobacco hornworm (Manduca sexta (L.); Perkins et al., 2004) and the grasshopper Schistocerca americana (Drury). Thus, a unimodal 'functional response' to dietary P-content may be a general phenomenon in herbivorous animals.

In the context of the findings of Plath \& Boersma (2001) and previous work with Daphnia, we suggest that Mexithauma at Cuatro Ciénegas exist on a 'stoichiometric knife edge' (Fig. 4). Under normal conditions, stromatolite $\mathrm{C}: \mathrm{P}$ ratio is high, resulting in P-limitation of growth and thus strong selection for reduced biomass P-requirements, as reflected in Mexithauma's relatively low average $\mathrm{P}$ content. Coincident with selection for low body $\mathrm{P}$ requirement would be evolution of reduced maximal growth capacity $\left(\mu_{\max }\right)$, given the association of body $\mathrm{P}$ content and growth capacity via the RNA mechanism 


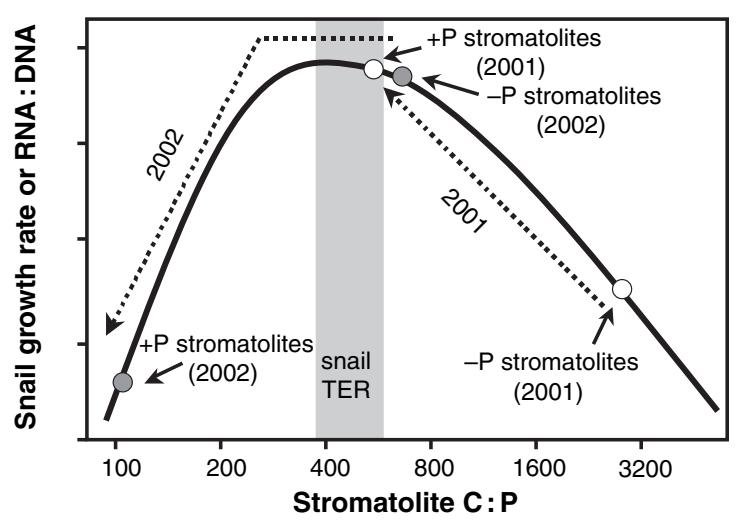

Fig. 4 Hypothesised 'stoichiometric knife-edge' indicated by the results of our two field experiments and illustrating the response of snail performance (e.g. growth or the growth indicator RNA : DNA ratio) to the two manipulations of stromatolite $\mathrm{C}: \mathrm{P}$ ratio. The grey shaded region indicates a likely range for the threshold elemental ratio (TER) based on the body $\mathrm{C}: \mathrm{P}$ ratio of Mexithauma. In 2001, initial stromatolite C : P ratio was extremely high and the relatively short-term P-enrichment reduced $\mathrm{C}: \mathrm{P}$ ratios closer to, but still greater than, those in Mexithauma's body tissue. Thus, snail performance was enhanced (dotted arrow labelled '2001') because of the reduction in stoichiometric mismatch between the snail and its food. In 2002, stromatolite C : P ratios were generally lower and P-enrichment resulted in very low $\mathrm{C}: \mathrm{P}$ ratios in stromatolite biomass, well below the $\mathrm{C}: \mathrm{P}$ values of the snails themselves. This resulted in decreased grazer performance (dotted arrow labelled '2002'), as observed for Daphnia by Plath \& Boersma (2001).

proposed by Elser et al. (2000b)). Thus, Mexithauma are likely to have little ability to respond in terms of increased growth even when stoichiometric constraints because of $\mathrm{P}$ supply are relaxed. If stromatolite $\mathrm{C}: \mathrm{P}$ ratios are chronically high, then we would also expect Mexithauma to respond in evolutionary time with physiological adaptations in digestion and excretion that would maximise assimilation and retention of dietary P. These hypothesised evolutionary responses may help in understanding why Mexithauma would be severely impaired when exposed to unnaturally low $\mathrm{C}: \mathrm{P}$ ratios in its food supply. Given such a P-rich diet, high efficiency in $\mathrm{P}$ assimilation and retention coupled with a modest ability to convert acquired resources into new biomass (low $\mu_{\max }$ ) may have resulted in direct P-poisoning because of excess $P$ supply in the 2002 experiment. More experimentation using a gradient of P-enrichment levels is needed to confirm the existence and shape of this 'knife-edge'. Intensive studies of the ecophysiology of Mexithauma would also be instructive.
To the extent that conditions encompassed in the 2001 experiment are representative of conditions affecting stromatolite-based food webs at the Precambrian-Cambrian transition, our data are supportive of a hypothesised role (Elser, 2003) for a relief of stoichiometric constraints in contributing to expansion and diversification of Metazoa during the Cambrian explosion. At least some palaeoenvironmental data suggest that stromatolitic microbes in the Precambrian grew under conditions that would generate severe P-limitation and high biomass C : P ratio. First, the early Earth had high concentrations of atmospheric $\mathrm{CO}_{2}$ and thus also had high aqueous $\mathrm{pCO}_{2}$ levels (Kasting, 1992). High $\mathrm{CO}_{2}$ availability generally favours production of biomass with high $\mathrm{C}$ : nutrient ratio in autotrophs (Sterner \& Elser, 2002; Urabe, Togari \& Elser, 2003); thus, high $\mathrm{pCO}_{2}$ levels in Precambrian ecosystems may have been partially responsible for maintaining high biomass $\mathrm{C}: \mathrm{P}$ in ancient microbial mats. It also appears that Earth's early oceans were quite low in bioavailable $\mathrm{P}$, as the biogeochemical $\mathrm{P}$ cycle was not yet fully engaged (Brasier \& Lindsay, 1998; Bjerrum \& Canfield, 2002). Processes of calcification associated with stromatolite morphogenesis may have further lowered $\mathrm{P}$ availability to stromatogenic microbes because of coprecipitation of $\mathrm{PO}_{4}^{3-}$ with $\mathrm{CaCO}_{3}$, as in modern calcareous environments (Fourqurean, Zieman \& Powell, 1992; Koch, Benz \& Rudnick, 2001). These factors showed significant changes during the Precambrian-Cambrian transition. It is well known that accumulating organic matter in the seas and on land was continuously lowering atmospheric $\mathrm{CO}_{2}$ levels (and raising $\mathrm{O}_{2}$ ) during the Precambrian (Kasting, 1992). Intriguingly, it is also known that a geochemical signal coincident with the Cambrian transition in the sedimentary record is the appearance of massive phosphorite deposits (Cook \& Shergold, 1984; Lambert et al., 1992; Shen, Schidlowski \& Chu, 2000). These deposits have been interpreted as the result of changes in tectonic movements coupled to altered hydrothermal activity and oceanic circulation patterns resulting in the upwelling of P-rich oceanic bottom waters in the shallow seas (Brasier \& Lindsay, 1998; Shen et al., 2000).

Thus, we suggest that a convergence of lower $\mathrm{CO}_{2}$ levels and higher $\mathrm{PO}_{4}{ }^{3-}$ supplies at the PrecambrianCambrian boundary alleviated stoichiometric constraints that had previously been limiting the ecological 
and evolutionary expansion of the Metazoa. Conversely, our 2002 data showing deleterious effects of low $\mathrm{C}: \mathrm{P}$ in stromatolite biomass suggest a flip side of this scenario: biogeochemical changes that radically increased the nutrient content of autotroph biomass may be an unappreciated factor causing decline or extinction of certain consumer taxa during other periods in the history of life. While our data provide tentative support for potential stoichiometric effects on the early evolution of metazoans, the stoichiometric hypothesis requires further testing, both in the palaeoenvironmental record to the extent that this is possible (for example, using palaeoindicators of biomass stoichiometry; Watanabe, Martini \& Ohmoto, 2000), as well as in longer-term field experiments that explicitly test the shape of the hypothesised 'stoichiometric knifeedge' for Mexithauma and also for other herbivorous animals. However, by integrating ecosystem ecology with evolutionary and developmental biology, this hypothesis holds the prospect of further illuminating the multivariate mechanisms that may have underpinned one of life's most important episodes.

\section{Acknowledgments}

This work was funded by the NASA Astrobiology Institute (grant NCC2-1051). J. Goebel (deceased) and S. Nag assisted with laboratory and field work and E. Saint Pierre determined snail lengths. This paper is dedicated to the memory of John Goebel.

\section{References}

Andersen T. (1997) Pelagic Nutrient Cycles: Herbivores as Sources and Sinks. Springer-Verlag, Berlin.

APHA (1999) Standard Methods for the Examination of Water and Wastewater. American Water Works Association, Washington, DC.

Bjerrum C.J. \& Canfield D.E. (2002) Ocean productivity before about $1.9 \mathrm{Gyr}$ ago limited by phosphorus adsorption onto iron oxides. Nature, 417, 159-162.

Boersma M. (2000) The nutritional quality of P-limited algae for Daphnia. Limnology and Oceanography, 45, 1157-1161.

Brasier M.D. (1990) Nutrients in the early Cambrian. Nature, 347, 521-522.

Brasier M.D. \& Lindsay J.F. (1998) A billion years of environmental stability and the emergence of eukaryotes: new data from northern Australia. Geology, 26, 555-558.
Brett M.T., Muller-Navarra D.C. \& Park S.K. (2000) Empirical analysis of the effect of phosphorus limitation on algal food quality for freshwater zooplankton. Limnology and Oceanography, 45, 15641575.

Cook P.J. \& Shergold J.H. (1984) Phosphorus, phosphorites, and skeletal evolution at the Precambrian-Cambrian boundary. Nature, 308, 231-236.

Davidson E.H., Peterson K.J. \& Cameron R.A. (1995) Origin of bilaterian body plans - evolution of developmental regulatory mechanisms. Science, 270, 13191325.

DeMott W.R., Gulati R.D. \& Siewertsen K. (1998) Effects of phosphorus-deficient diets on the carbon and phosphorus balance of Daphnia magna. Limnology and Oceanography, 43, 1147-1161.

Elser J.J. (2003) Biological stoichiometry: a theoretical framework connecting ecosystem ecology, evolution, and biochemistry for application in astrobiology. International Journal of Astrobiology, 3, 185-193.

Elser J.J., Schampel J.H., Garcia-Pichel F., Wade B.D., Souza V., Eguiarte L., Escalante A. \& Farmer J.D. (2005) Effects of phosphorus enrichment and grazing snails on modern stromatolitic microbial communities. Freshwater Biology, 50, 1808-1825.

Elser J.J., Sterner R.W., Gorokhova E., Fagan W.F., Markow T.A., Cotner J.B., Harrison J.F., Hobbie S.E., Odell G.M. \& Weider L.J. (2000b) Biological stoichiometry from genes to ecosystems. Ecology Letters, 3, 540550.

Elser J.J., Fagan W.F., Denno R.F. et al. (2000a) Nutritional constraints in terrestrial and freshwater food webs. Nature, 408, 578-580.

Erwin D.H. (1993) The origin of metazoan development: a palaeobiological perspective. Biological Journal of the Linnean Society, 50, 255-274.

Fourqurean J.W., Zieman J.C. \& Powell G.V.N. (1992) Phosphorus limitation of primary production in Florida Bay - evidence from C-N-P ratios of the dominant seagrass Thalassia testudinum. Limnology and Oceanography, 37, 162-171.

Gorokhova E. \& Kyle M. (2002) Analysis of nucleic acids in Daphnia: development of methods and ontogenetic variations in RNA-DNA content. Journal of Plankton Research, 24, 511-522.

Grotzinger J.P. \& Knoll A.H. (1999) Stromatolites in Precambrian carbonates: evolutionary mileposts or environmental dipsticks? Annual Review of Earth and Planetary Science, 27, 313-358.

Hershler R. (1985) Systematic revision of the Hydrobioidae (Gastropoda: Rissoacea) of the Cuatro Ciénegas basin, Coahuila, Mexico. Malacologia, 26, 31-123. 
Kasting J.F. (1992) Proterozoic climates: the effect of changing atmospheric carbon dioxide concentrations. In: The Proterozoic Biosphere (Ed. J.W. Schopf \& C. Klein), pp. 165-168. Cambridge University Press, Cambridge.

Knoll A.H. \& Carroll S.B. (1999) Early animal evolution: emerging views from comparative biology and geology. Science, 284, 2129-2137.

Koch M.S., Benz R.E. \& Rudnick D.T. (2001) Solid-phase phosphorus pools in highly organic carbonate sediments of northeastern Florida Bay. Estuarine, Coastal and Shelf Science, 52, 279-291.

Lambert I.B., Beukes N.J., Klein C. \& Veizer J. (1992) Proterozoic mineral deposits through time. In: The Proterozoic Biosphere (Ed. J.W. Schopf \& C. Klein), pp. 59-62. Cambridge University Press, Cambridge.

Loladze I., Kuang Y. \& Elser J.J. (2000) Stoichiometry in producer-grazer systems: linking energy flow and element cycling. Bulletin of Mathematical Biology, 62, 1137-1162.

McMenamin M.A.S. (1988) Paleoecological feedback and the Vendian-Cambrian transition. Trends in Ecology and Evolution, 3, 205-208.

Perkins M.C., Woods H.A., Harrison J.F. \& Elser J.J. (2004) Dietary phosphorus affects the growth of larval Manduca sexta. Archives of Insect Biochemistry and Physiology, 55, 153-168.

Plath K. \& Boersma M. (2001) Mineral limitation of zooplankton: stoichiometric constraints and optimal foraging. Ecology, 82, 1260-1269.

Raff R.A., Marshall C.R. \& Turbeville J.M. (1994) Using DNA sequences to unravel the Cambrian radiation of the animal phyla. Annual Review of Ecology and Systematics, 25, 351-375.

Shen Y., Schidlowski M. \& Chu X. (2000) Biogeochemical approach to understanding phosphogenic events of the terminal Proterozoic to Cambrian. Paleaeogeography, Palaeoclimatology, Palaeoecology, 158, 99-108.

Sterner R.W. \& Elser J.J. (2002) Ecological Stoichiometry: The Biology of Elements from Molecules to the Biosphere. Princeton University Press, Princeton, NJ.
Effects of stromatolite $P$ enrichment on grazers

Sterner R.W. \& Hessen D.O. (1994) Algal nutrient limitation and the nutrition of aquatic herbivores. Annual Review of Ecology and Systematics, 25, 1-29.

Sterner R.W. \& Schulz K.L. (1998) Zooplankton nutrition: recent progress and a reality check. Aquatic Ecology, 32, 261-279.

Thomas A. (1997) The breath of life - Did increased oxygen levels trigger the Cambrian explosion? Trends in Ecology and Evolution, 12, 44-45.

Urabe J. \& Sterner R.W. (1996) Regulation of herbivore growth by the balance of light and nutrients. Proceedings of the National Academy of Sciences of the United States of America, 93, 8465-8469.

Urabe J. \& Watanabe Y. (1992) Possibility of $\mathrm{N}$ or $\mathrm{P}$ limitation for planktonic cladocerans: an experimental test. Limnology and Oceanography, 37, 244-251.

Urabe J., Togari J. \& Elser J.J. (2003) Stoichiometric impacts of increased carbon dioxide on a planktonic herbivore. Global Change Biology, 9, 818-825.

Urabe J., Elser J.J., Kyle M., Sekino T. \& Kawabata Z. (2002) Herbivorous animals can mitigate unfavorable ratios of energy and material supplies by enhancing nutrient recycling. Ecology Letters, 5, 177-185.

Valentine J.W. (1973) Evolutionary Paleoecology of the Marine Biosphere. Prentice-Hall, Inc., Englewood Cliffs, NJ.

Watanabe Y., Martini J. \& Ohmoto H. (2000) Geochemical evidence for terrestrial ecosystems 2.6 billion years ago. Nature, 408, 574-578.

White T.C.R. (1993) The Inadequate Environment: Nitrogen and the Abundance of Animals. Springer-Verlag, New York.

Zhuravlev A.Y. \& Riding R. (2001) The Ecology of the Cambrian Radiation. Columbia University Press, New York.

(Manuscript accepted 3 November 2004) 